\title{
Bilimsel Renk Bilgisinin Resim Sanatındaki Yansımaları
}

Sevgi $\mathrm{AVCl}$ *

Özet

Renk, sanatın duyusal izlenim taşıyan doğaya öykünme, idealize etme ve soyutlaştırma temelli serüveninde, ressamın imgelerini kurmak için kullandığı temel araçlardan biridir. Sanatın bilim öncesi ya da yansıtmaya dayalı döneminde renk ve ışık iki ayrı kavramdır. Sanatçılar bu ikisi arasındaki ilişki üstüne pratikler yaparken, bilim adamları yalnızca ışığa odaklanmıştı. Ancak, bilim ve sanatın ortak konusu ışığın enine boyuna incelenmesi, yüzlerce yıl araştırma yapan bilim ve sanat insanını renk konusunda buluşturdu. Newton'un bilimsel buluşu ile renk, sanat dünyası dışında da ele alınan konu olarak özellikle 19. yüzyılın keşifler atmosferinde yapısal özellikleri, görme, algılama ve ilişkileri yönünden araştırılmaya başlanmış; üstüne üretilen teoriler resim sanatı pratiklerine yansımıştır. Renk hakkındaki metinler, sanatçının renk anlayışına yeni boyut katarken renk deneyiminde biçimden bağımsılaşıp salt görsel olana yönelik dönüşümü sağlayan faktörlerden biri olmuştur. Rengin bilim sonrası kullanımını içeren bu makalede bilimsel renk bilgisinin resim sanatındaki etkilerini incelemek amaçlanır.

Anahtar Sözcükler: Bilimsel Renk Bilgisi, Resim Sanatı, Renk, Işık. Renk Duyumu, Renk Algısı

\section{The Reflections of Scientific Colour Knowledge on the Art of Painting}

\section{Abstract}

Colour is one of the main devices that painters use in creating images through a process of abstraction, idealization and imitation of nature which embody perceptual impressions. Colour and light were two distinct concepts in art before the age of science. While artists were working on the relationship between the two, scientists were focused only on light. However, colour was to be the meeting ground for scientists and artists who seperately had been studying light for centuries. Following Newton's discovery, in the 19th century, colours began to be studied from the point of their perceptual and structural qualities and relations outside of art, and in turn such theories had an impact on artistic practice. While scientific texts on colour contributed to artists' understanding of colour; they also had been one of the factors that led the way to the evaluation of the visual regardless of form. This article aims to examine the effects of scientific knowledge of colour on the art of painting. 


\section{Giriş}

Resmin temel ögelerinden biri olan renk, sanatın duyusal izlenim taşıyan doğaya öykünme, idealize etme ve soyutlaştırma temelli pratiklerine eşlik etmiştir. Sanat ve bilim alanında renk hakkında üretilen bilginin alışverişi, resimde rengin bu işlevini deḡiştirmese de kullanımına ve resmin içeriğine yön vermiştir.

Sanatın bilim öncesi ya da yansıtmaya dayalı döneminde renk ve ışık iki ayrı kavramdır. Sanatçılar bu ikisi arasındaki ilişki üstüne pratikler yaparken, rengi nesnenin bir özelliği saydıklarından, nesneyi aydınlatan ışığın izini sürmüşlerdi. ışık, estetik bakımdan, lokal rengin, yani nesnenin varlığına ait olarak düşünülen rengin, açı/koyu deḡerleri ile elde edilip yüzey üzerinde hacmi ortaya çıkarmaya yarıyordu. Resimde en üst düzeyde gerçeklik yanılsamasına ulaşmak için renk ilişkilerinde ışık ve derinlik etkisine başvuruldu. Bu uğurda görmeyi rasyonelleştiren çeşitli gözlem teknikleri ve araçlar dahi geliştirildi. Bilim adamları ise başlangıçta yalnızca ışığa odaklanmıştı. Ancak, optik araştırmalar sırasındaki deneylerde ışığın kırılımı ile rengi meydana getirdiğini keşfeden Sir Isaac Newton (1642-1727), ışığı rengin kaynağı olarak tanımladı; sanat geleneğinden bağımsız, matematiksel verilerle ve rakamlarla ifade etti. Dolayısı ile renk, Fizik, Fizyoloji, Kimya, Biyoloji, Psikoloji ve Sosyoloji'nin inceleme alanına girmiş, sanatla bilimin yolu renk konusunda kesişmiştir.

Renk bilgisinin bilim ve sanat eksenindeki iki yüzyıldan daha fazla zamana yayılan tarihi gelişiminde, fizikte ışığın kırılması ile başlayıp sanatta illüzyonun kırılmasıyla devam eden iki ayrı dönüm noktası yaşandı.

ilkinde, Newton'un keşfinden sonra bilim dünyasında renk, yapısal özelliği, görme, algılama ve ilişkileri yönünden incelenmiş; özellikle 19. yüzyılda, renk üstüne odaklanan bilim adamlarından Johann Wolfgang von Goethe-1810(1749-1832), Thomas Young (1773-1829), David Brewster (1781-1868), Michel Eugène Chevreul-1839 (1786-1889), Von Helmholtz-1878 (1821-1894), Ogden Nicholas Rood-1881 (1831-1902) ve Karl Ewald Konstantin Hering (1834-1918) geliştirdikleri teorileri ile öne çıkmışlardı.
İkincisinde ise, renk üstüne bilimsel çalışmaların sanata yansıması söz konusudur. Bilim alanında renk hakkındaki metinler, renk pratiklerinde sanatta dönüşümlere yol açan gelişmeler sağladı. Örneğin, sanatçının renge bakışı değişti; birçok -Fransız, İtalyan ve Amerikan- ressamın soyutlamaya doğru yönelmesinde ilham kaynağı oldu; renk kavramının ışıkla bağına yeni boyut kattı. Moszynska’nın (1993:15) Abstract Art (Soyut Sanat) adlı kitabında belirttiği gibi: "Yeniçağın bakış açısından gelişen teoriler, sanatçıların nesneyi esas alan sanat yaklaşımından, rengin özgürleşmesini araştırabilecekleri bir yapıya doğru giden sanatın koşullarını hazırladı”.

Bu makale, rengin bilim sonrası resim sanatında kullanımını kapsar. Renk konusunun geniş kapsamı nedeniyle, ağırlıklı olarak Fizik, Fizyoloji ve Görsel Algılama alanındaki renk teorilerine yoğunlaşır ve bu alanlarda üretilen renk bilgisinin, resim sanatına evrilmesinden doğan etkilerini örneklerle incelemeyi amaçlar.

\section{Bilimden Sanata Rengin Anlamı: Işıktan Renge-Renkten Işığa}

Işık, resim sanatında rengi bilime taşıyan unsurdur. Çünkü, bilimsel buluşlar, renkle bağı nedeniyle ışığı, ressamın ilgi odağı haline getirmiştir. Bilimdeki tanımıyla “ışık, bir enerji kaynağından göze gelen ışının elektromanyetik dalgalara dönüşmüş halidir" (Temizsoylu, 1987: 10). Renk ise ışığın bir özelliğidir: "Görülebilen her dalga boyundaki ışık özel bir renk hissinin doğmasına yol açmaktadır. Normal bir insan gözü dalga boyu 380-760 nm arasında olan ışığı algılayabilmektedir" (Daw,1992: 545-561; Kamış, vd, 2001:732'den). Sanat dışındaki alanlarda renk tanımlarının temelinde ışık vardır: "Fiziksel sistemde renk: Işığın, ölçüler ve rakamlarla geniş bir şekilde incelendiği olaylar topluluğudur. Fizyolojik sistemde renk: Işığın, göz retinası üzerinde ve sinirlerde meydana getirdiği deḡişimdir. Psikolojik sistemde renk: Çeşitli ışık etkilerinin beyinde uyandırdığı etkilerdir." (Temizsoylu, 1987: 9). Resim sanatında hangi dönem, hangi üslup olursa olsun renk ışıkla ilişki halindedir. Bilimsel deneylerde nesnelerin rengi, üzerine düşen ışık ile deḡiştiği gözlemlenip rengin bir duyum olduğu kavrandıktan sonra, ışık kavramı ile eskiden olduğu gibi resimde açık koyu deḡer farkları 
değil, bir duyum olarak renkler ve renklerin kroma deḡeri kastedilecekti. Bilimin aksine resimde renk, ışığın kaynağıdır. Modern resimde ışıkla aynı anlamda kullanılmıştır. Başka deyişle, her bir rengin ışığa karşılık geldiği, renklerin farklı ışık değerine sahip olduğu anlaşılmıştır.

\section{Sanat Dünyasında Renge Bilimsel Yaklaşımlar: Nesnel Görmeden Öznel Görmeye Doğru}

Sanatsal bilgi üretiminde renk kullanımı hakkında resim sanatının evrimi kendi içinde sürerken, renkle ilgili bilimsel çalışmalar 17. yüzyılda başladığı halde bu konudaki bilimsel bilginin sanata katkısı gecikmeli olmuştur. Çünkü, dönemin sanat alışkanlığı/geleneg̃i böylesi estetik yenilenmeye henüz hazır değildir. Bu yüzden loş atölye ortamından gün ışığına/doğaya çıkıp gözlem yapmaya başlandığında renkleri görme, hatta görmeden de öte görüldüğü gibi resmetme bazı sanatçıları, sanat çevrelerini çelişkiye sürüklemiştir. Gombrich (1992: 64), bunu sanatçı-izleyici veya devrim-gelenek arasındaki çatışmalara bağlar. Ressam, günışığı altında renklerin parlak olması durumunu fark etmiş bile olsa resminde kullanma konusunda tereddüt yaşar; izleyicinin beğenisine ters düşmesi nedeni ile eskisi gibi renkleri kahverengi ve mavi tonları etrafında sınıflandırmak zorunda kalır. Diḡer yandan bu dönemde bilim ve sanatın ayrı ayrı alanlar olarak tarifi bilimsel yaklaşımları sanatın dışında tutar. Bilimde neden sonuç ilişkisi içinde 'nesnel değişmezlik', ilkesi ile açıklanabilen renk göreceliliği, doğadaki ışığın deḡişken olması yüzünden bu durum resimde nesnel olarak yansıtılamaz. Yani ressamın doğa gözlemi özneldir. Diğer yandan resme ne kadar ışık girerse resim o oranda klasik beḡeniden uzaklaşmış kabul edilir. Algılama üstüne yapılan siyah kömür-beyaz mendil deneyinde küçültme ekranı diye adlandırılan ve ışıklandırmanın derecesi konusunda yargıya varmayı sağlayan, aygıt yardımı ile gölgedeki beyaz mendile göre güneş ışığı altında, daha beyaz görünen kömürün renk göreceliliği bilimsel olarak ispatlanır (Gombrich, 1992: 65). Algılama açısından asıl olan görece nitelikteki parlaklıktır. Görmenin fizyolojik işleyişinde renklerin ressamlarca bu şekilde duyumu sanat tarihindeki kırılmanın da başlangıcıdır.

Renk görmenin, görsel algılamanın bir parçası olduğu düşünülürse, ressamların görsel algılama alanındaki çalışmalara benzer biçimde onlardan çok daha önce görme deneylerine girişmeleri, sanat alanındaki bilimsel yaklaşımların sinyalidir. 17. yüzyıl manzara resminde renk görme ile ilgili çabaların bir ürünü olarak Claude Lorrain'ın (1600-82) yüzeyi karartılmış cama başvurması bu tavra kanıt olabilir. Sanatçılar, özellikle manzara resminde ışık ve derinlik etkisi verme çabalarında mutlak renge ulaşmak için yeni gözlem tekniklerinden yararlandılar (Warner, 2005: 865-866). Gerçekliğin temsili uğruna, isli camdan küçültme aynasına, Camera obscura'dan fotoğraf makinasına kadar, en basitten en karmaşığa çeşitli aygıtlar icat edildi.

Sir Joshua Reynolds (1723-92) ve Thomas Gainsborough (1727-88) gibi ressamlar, doğayı tasvir etse de görüngü, henüz imgeleme dayalıdır ve loş atölye ortamında üretilir. Renkten yararlanma biçimleri eskisi gibi açı/koyu tonlama ile keskin çizgi ve hacim yakalamak, sağlam biçimler yaratmak şeklinde olduğundan gözlemlerinde doğa muhalefeti ile karşılaşmaları kaçınılmazdır.

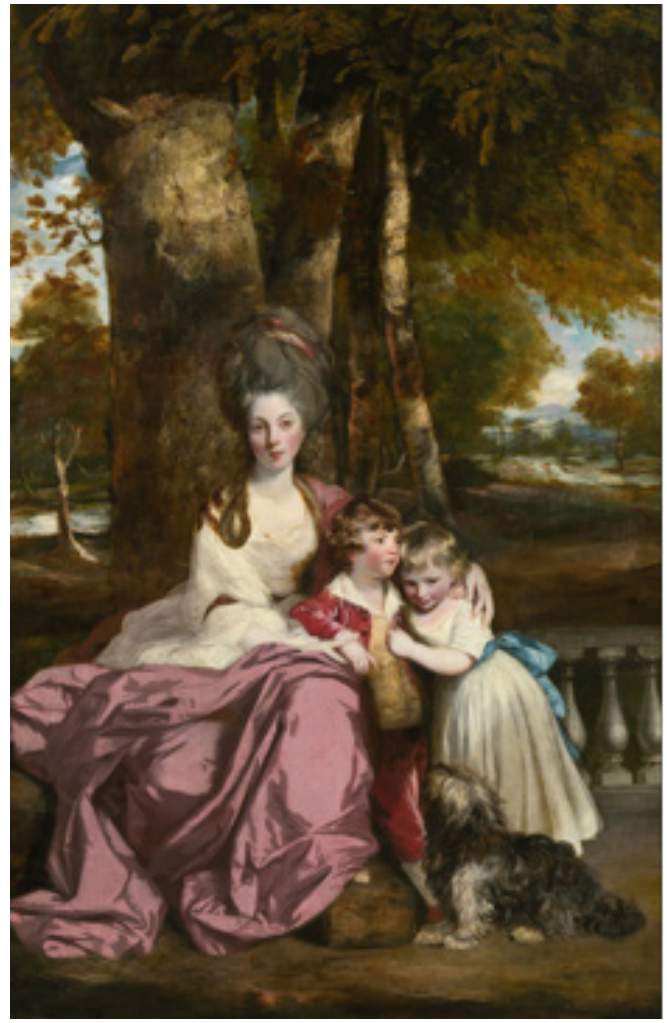

Resim 1. Sir Joshua Reynolds, 'Laydi Elizabeth Delmé ve Çocukları', 1777-89 Tuval Üzerine Yağlıboya, 238.4x147.2 cm. Ulusal Sanat Galerisi, Washington, D.C 


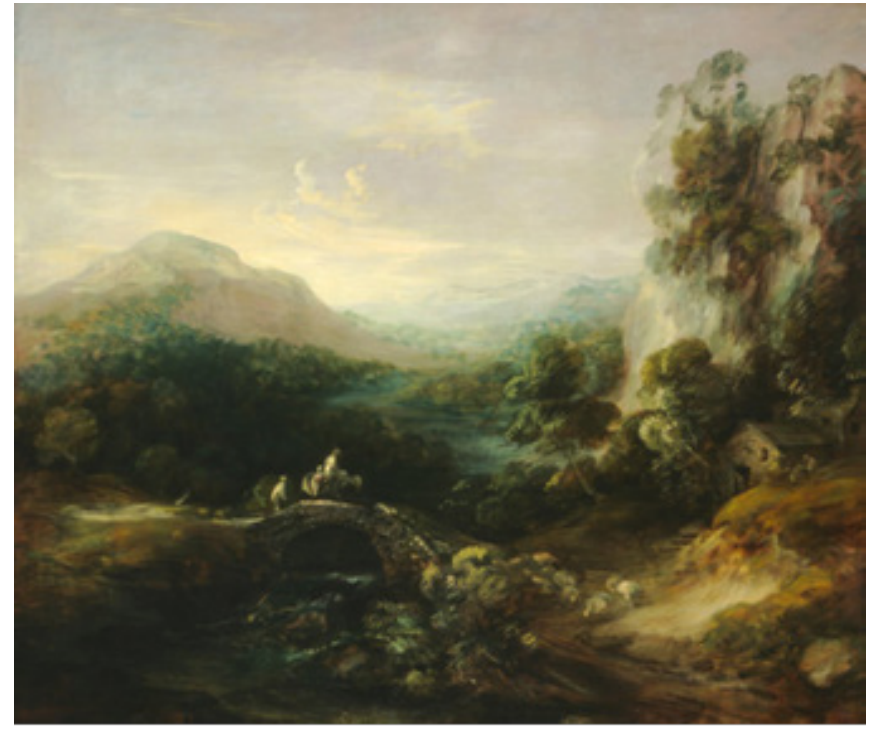

Resim 2. Thomas Gainsborough. ‘Köprülü Peyzaj’, 1783-84 Tuval Üzerine Yağlıboya, $113 \times 133.4$ cm. Ulusal Sanat Galerisi

Ancak, 18. yüzyılda öncülü isli cam olan ve Lorrain aynası diye adlandırılan küçültme aynası adlı bir aygıt geliştirilir. (Gombrich,1992: 60, 61) Sürekli değişen ışık altında öztonu zayıflatan bu aygıt yardımı ile nesneler üzerinde patlayan şiddetli ışığın üstesinden gelinir. Doğanın çok renkliliği, uzaklarda soluk maviden ön planda koyu kahverengiye doğru yumuşak geçişlerle renk derecelendirmeleri denenerek elde edilir. Ve böylece doğadaki açık koyulara sadık kalmanın; renk tonları arasındaki ilişkileri koruyarak tuvale taşımanın yolu bulunur. Sir Joshua Reynolds'un 'Lady Elizabeth Delmé ve Çocukları' (Resim 1), Thomas Gainsborough'un 'Köprülü Peyzaj' (Resim 2) adlı resimlerinde ışık ve derinlik etkisi vermek için bu aygıttan nasıl yararlandıklarını görmek mümkündür.

Buluşlar çağı olan 19. yüzyıl başlarında çalışmalarının 'doğa bilimsel deneyler' olduğunu söyleyen. John Constable (1776-1837), bilimsel tutumu ileriye götüren örnek olarak günümüzde artık yadırganmayan aydınlık palete ulaşmanın ilk adımını atar. Doğadaki açık koyu etkileri, ressamın sınırIı paletinde araştıır. Hassas renk dereceleri ve renkler arası ilişkilere yoğunlaşır. Canlı renk kullanma girişiminde bulunur. Nitekim 'Saman Arabası' adlı resmi, Paris'te sergilendiğinde, Empresyonist sanatçıların renklendirme deneyimlerine ilham vermiştir. Constable, derinlik etkisini ve resmin atmos- ferine hakim olan ışığı öznel renk duyumu ile sağlayarak lokal renk anlayışının çözülmesinde öncü olmuş, ışık ile renk arasındaki güçlü bağı sezmiştir (Resim 3).

Constable örneğinde sanatçıya muhalefet eden bu kez doğa değil, bilimdir. Onun parlak yeşilleri Delacroix'ya (17981863) cesaret vermesine rağmen, sanat tarihinde, resmin ön planında kahverengilerin yerine geçen parlak yeşillerle ilgili anlatılagelen anekdot, Constable'ın renklerle deneyimlerinin, bilim adamlarını, örneğin Brückéyi tatmin etmemesini, aynı şekilde dönemin sanat takipçisi, bazı meslektaşları ve izleyicileri arasında da tepkilere yol açmasını yansıtır (Gombrich, 1992:61-62).

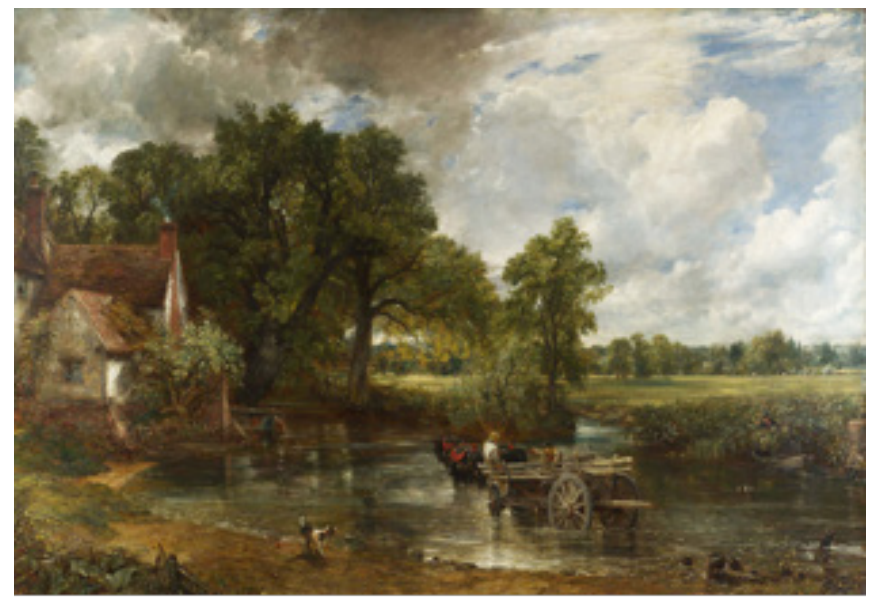

Resim 3. John Constable, 'Saman Arabası', 1821

Tuval Üzerine Yağlıboya, $130.2 \times 185.4$ cm. Ulusal Galeri, Londra

Görme fizyolojisinin duyum olarak işlemesi, özellikle empresyonistlerin üstüne gittiği bu durumu daha önce fark eden Constable'ın, Camera obscuránın çerçevesinde beliren görme kuralından vazgeçmesi ve 'doğa bilimsel deneyler' dediği doğa gözlemlerini içeren çalışmalarında, boyalarla ışı̆̆ kaydedip duyumlarını aktarması ile sanatın da meselesi oldu.

19. yüzyıl başlarına kadar gerçek dünyanın görüntüsünü onaylama uğraşısı veren göz organı, mekanik aygıtlardan vazgeçip akılla iş birliği yapması ile bedene dönüşerek, bilim dünyası algılama sürecinin kendisini mercek altına alıyordu. Johann Wolfgang Von Goethe (1749-1832), Arthur Schopenhauer (1788-1860), John Ruskin (1819-1900) Roger Fry (1866-1934) ve daha pek çok araştırmacı algılama sürecini incelediler (Crary, 2004: 150). 
19. yüzyıl başında Newton optiğine karşı Almanya'da oluşan genel tepkinin bir parçası olarak Schopenhauer ve Goethe, Newton'a cephe almışlardır. Goethe ressam ve şair olarak sezgileri ile rengin bilimsel yönünü algılama açısından ele alır. 1786'dan itibaren, rengin sanattaki kullanım kuralları üstüne araştırmaları 1840'larda Goethe teorisi olarak dünyaya yayılacaktır. O'nun sezgilere dayanan teorisi, sanat ve bilim dünyasındaki bilginin alışverişine ivme katması bakımından önemlidir. Goethe, ilk kez 1810 'da yayınlanan ve 'Renk Öğretisi' adı altında dilimize de çevrilen kitabında renk için; "... genel geçerli doğa formülleri arasında en iyi görülebilen ve kavranabilen, göz organını anlamlaştıran ve böylece göz duyusuna hitap eden en temel doğa olgusudur" (Goethe,2013:28) demektedir. Işığın fark edilmesi ve bunun sonunda, beyne ulaşan duyumların algılanma ve yorumlanması ile renklerin ortaya çıktığını öne sürer. Renk açıklamasında fizyolojik fenomeni vurgularken insan faktörünü dikkate almaksızın salt nesnel gerçeği tanımlamaya çalışır. Renkleri oluşumuna göre, gözün etki ve tepkisini çekmesi bakımından fizyolojik, algılanabilmesi açısından fiziksel, nesnelerle ilişkilendirilmesinde ise kimyasal olarak nitelendirir. Görülebilir nesnelerin ışık ve algıya bağlı olduğunu düşünerek gözlemlerinde daha çok gözde oluşan sanal görüntüler, renkli gölgeler ve tamamlayıcı renkler üzerine odaklanmıştır. Renklerin aydınlık, karanlık, parlaklık ve belirsizlik gibi farklı ışık altındaki durumlarını incelemiştir. Newton'un aksine renklerin sadece ışı̆ı̆ın davranışı ile meydana gelen fiziksel şartlardan kaynaklanmadığını, görmenin fizyolojisi yüzünden bu şekilde algılandığını savunmuştur.

Schopenhauer ise, nesnel gerçeği ön planda tutan Goethe'den farklı olarak görmeyi öznelleştiren bir yaklaşım sergiler. Sadece fizyolojik boyutu dikkate alır. Ona göre renk, retinanın tepkileri ve etkinliği ile eş anlamlıdır ve bu yüzden renk görme, bedeni de kapsayan bir etkinliktir. Fakat, ikisinin ortak yanı, rengi önemsemek ve renk açıklamasında fizyolojik fenomeni vurgulamaktır (Crary, 2004: 87). Schopenhauer'de duyumu oluşturan öznedir. Belli bir süre bakılan rengin, gözler kapalı olduğunda da görülmeye devam etmesi olgusu bunun göstergesidir.
O, beynin içinde, öznede gerçekleşen bu şeyin, dışında bir dünyada gerçekleşiyormuş gibi açıklanmasını yanlış bulmuştur. Şöyle ki: "Schopenhauer'in Camera obscura modelini ters yüz eden görüşünü 19. yüzyıl başlarındaki araştırmalar da destekledi. Bu araştırmalarda kör nokta, optik sinirin retinaya girdiği nokta olarak saptandı. Camera obscuránın aydınlatan deliğinin tersine Schopenhauer'in bakan kişisinde göz ile beyni ayıran nokta kesinlikle karanlık ve pusluydu" (Crary, 2004: 89). Metafizik karşıtlığında başı çeken isim Ernst Mach (1838-1916), 1885'te Schopenhauer ve Goethe'yi duyularla ilgili fizyolojinin kurucuları olarak nitelemiştir. Schopenhauer görme konusunda bilimsel ve estetik söylemi, modernite ve gözlemciyi anlamak konusunda 19. yüzyılda sanat ve bilimi ayrı olarak gören basitleştirici girişimlere meydan okumaktadır (Crary, 2004: 89).

Ruskin ve Fry görünür dünyanın nesnelerini yansıtma konusunda gözün üç boyutlu görmediği düşüncesindeydi. Ruskin'in 1856 tarihli metni on yıllar öncesinden Empresyonistlerin yapacaklarını dile getirir niteliktedir. Metne göre, katı cisimleri algılamak bütünüyle bir deneyim işidir. Dış dünyaya dair bütün görülen, nesnelerin yüzeyi üstündeki renklerdir. Siyah ya da gri bir lekenin katı bir cismin karanlık yanı olduğu ya da zayıf bir renklendirmenin ilgili nesnenin uzaklığını gösterdiği ancak bir dizi deney sonucu algılanır. Ruskin'in bu düşüncesi, Piskopos (George) Berkeley'in (1685-1753) New Theory of Vision (Görmenin Yeni Kuramı) adlı eserinde ortaya attığı görüşün uzantılarıdır. Berkeley'de görünen dünya, her bireyin yıllarca edindiği deneyimlerden kendine kurduğu bir yapıdır. Ona göre, göz aracılığıla algılananlar retinadaki uyarımlar ile oluşan renk duyumlarıdır. Duyumları algılamalara dönüştüren zihindir; algılamalar ise dünyaya ilişkin bilinç ürünü tasarımları meydana getiren öğelerdir; bu sebeple sözü edilen tasarım, deneyimi ve bilgiyi temel alır (Gombrich, 1993: 287). Berkeley felsefesi özünde resim sanatını retinada görme olgusuna indirgeyen süreci başlatıp ışık ve rengi mercek altına alır. Bu felsefenin ışığında 19. Yüzyıl ortalarında, Ruskin'in ressamdan kuramsal olarak beklediği retinadaki görüntüyü doğru yansıtmak için nesnelerle ilgili bütün bildiğini 
unutmasıdır. Berkeley uzantılı bu düşünce bağlamında, Constable'ın görünen dünyayı temsile dayalı 'Viwenhoe Parkı' (1816) betimlemesi doğanın yalnızca bir kopyası deḡil ışığa ve yağlıboyaya çevrilmiş gerçekliğe dair görünüşün de bir versiyonudur.

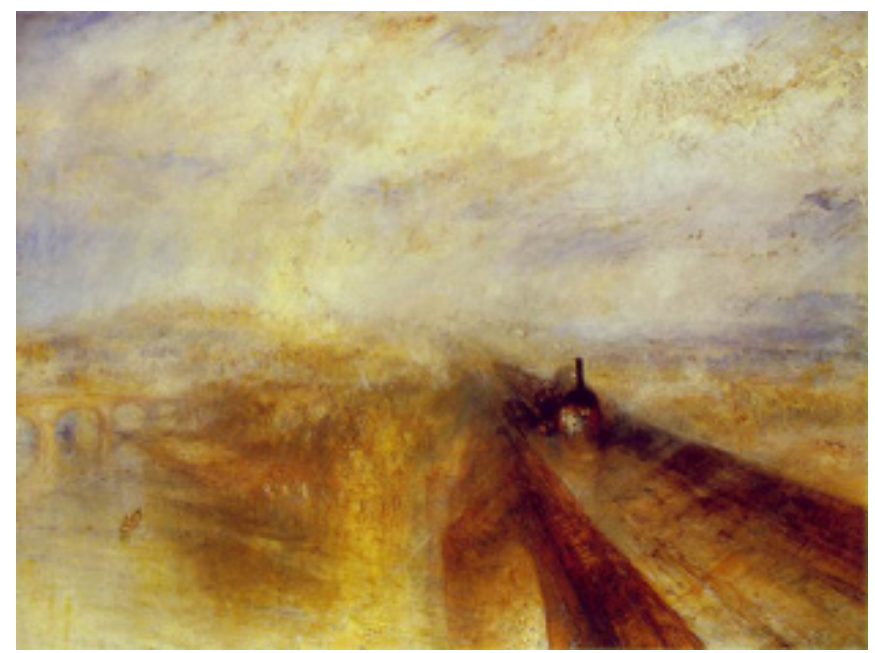

Resim 4. J. M. W. Turner, 'Yağmur, Buhar ve Hız', 1844

Tuval Üzerine Yağlıboya, $90.8 \times 121.9$ cm. Ulusal Galeri, Londra

Goethe'nin renk teorilerinden etkilenen Philipp Otto Runge (1777-1810), J. M. W. Turner (1775-1851), Rafael öncesi sanatçıları (The Pre-Raphaelites) (1848) ve Wassily Kandinsky (1866-1944), rengin açık-koyu, sıcak-soğuk gibi niteliklerini ve karşıt renk ilişkilerini hayata geçirdiler. Bunlar arasından William Turner, yapıtlarında Camera obscura ölçütlerinde görmenin çöküşünü tam anlamıyla gösteren isimdir. Tamamlayıcı renk etkileşimlerini kullanan Turner'ın resminde, imgenin bütün olarak algılanması hemen hemen olanak dışıdır. Onun dış dünyadaki nesneleri temsile dayanmayan görme biçiminde imge, bütün yüzeylerdeki renk ve ışığın devinim halinde birbiri ile kaynaştığı yansımalardan ibarettir. Boşlukta yayılan ışığın sonsuz sayıdaki kırılımı ile meydana getirdiḡi görsel soyutlamaları, resme konu olan görüntülerin, kalıcı olmayan renklerine dair gözlemlerin, duyumların tespitidir (Resim 4).

Kandinsky Münih'te, Goethe'nin sezgisel yaklaşımına Fransız renk teorisyenlerinin bilimsel temelinden daha yakındı. 'Sanatta Ruhsallık Üstüne' 1912'de yayınlanmış, renk hakkındaki önceki yazılarının, kesin bir bilime dayalı olma- yan fakat deneysel bir duyumsamanın sonucu olduğunu belirtmiştir. Goethe gibi Kandinsky de birçok anti tez listesi düzenlemiştir. Sarının maviye, beyazın siyaha, kırmızının yeşile, turuncunun mora karşıtlığını gösteren şemadan hareketle, sarı aktif sıcaklığı belirtip tipik yersel renk olarak, mavi aktif soğukluğu vurgulayan göksel renk olarak sınıflandırılır. Van Gogh gibi daha önceki sanatçılar, renkler ve hisler arasındaki bir ilişkiden bahsetmiştir. Fakat Kandinsky için en önemli nokta, renklerin objeler tarafından önceden belirlenmiş özelliklerini barındırabilmeleri için renklerin gramerine varabilmekti. Göksel özelliklerin, göğün rengi veya Madonna'nın giysisinin, maviye göndermesi gibi önemli olan mavinin tamamen temsili olmayan bir içeriğe yerleştirildiğinde bile halen bu özellikleri temsil ettiğinin görülmesidir (Moszynska, 1993: 27; Kandinsky, 2013: 80-85).

Kandinsky renklerle soyut ve kuramsal bir dil kurmaya çalışmıştır. Başlangıçta dış dünyanın görüntülerine bağlıymış gibi durmasına karşılık 1911-14 yılları arasında yaptığı resimlerde bundan sıyrıldığı görülür (Resim 5). Ona göre bir rengin duyumsal etkisi çok kısadır. Evrensel olan, renklerin yarattığı tinsel yankıdır; yani renklerle ruha dokunmak ve ruha ulaşmaktır. Kompozisyon dizilerinde renk ilişkilerini müziğe eşdeg̃erde bir yaklaşımla çözümler. Her bir rengi doğru titreşimi yakalamak için müzisyenin dokunduğu tuşlara benzetir (Farago, 2006: 187). Yukarıda adı geçen kitabında 'Formun ve Rengin Dili' başlığı altında renk biçim ilişkilerini kuramsal açıdan analiz etmiştir.

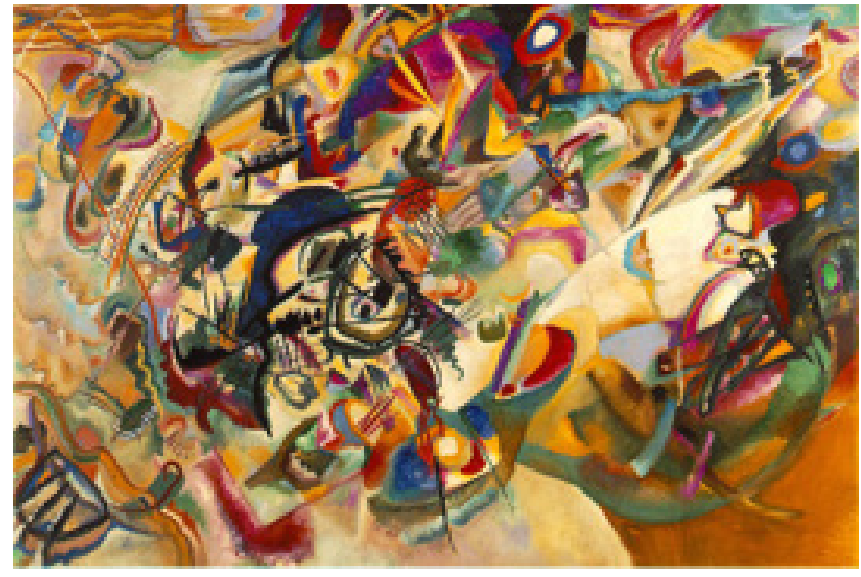

Resim 5. Wassily Kandinsky, 'Kompozisyon 7', 1913

Tuval Üzerine Yağlıboya, 200×300 cm. Tretyakov Galerisi, Moskova 
Johannes Itten (1888-1967) ve Paul Klee'nin (1879-1940) renk ilgisi, sadece resim pratiği ile sınırlı kalmayıp rengin algılanması bağlamında kuramsal çalışmalarda genişlemiştir. Itten, bilimsel geçerliliğini bugün de koruyan mevcut renk bilgisini, renklerin karşıtlık ilişkilerine göre, yedi maddede ele alır. İtten'e göre renk biliminin esaslarını ortaya koyan isimler; Goethe, Runge, Chevreul, Johann Friedrich Wilhelm von Bezold (1837-1907) ve hocası Adolf Hölzel (1853-1934) dir. İtten kitabın sunuş kısmında onların buluşlarının eşsiz bulduğunu; fikirlerini onların teorileri doğrultusunda yapılandırdığını belirtmiştir (Itten, 2005: 12). 1961 tarihli 'Kunst der Farbe' (Renk Sanatı) adlı kitabında renklerin algılanmaya bağli; sıcak soğuk etkisi, alan, tür, değer, ton ve yoğunluk niteliklerindeki değişim kriterlerini, çeşitli sanatçıların yapıtları üzerinden incelemiş; doğa gözlemlerinde ve deneylerde üretilen bilimsel teorileri adeta insan yaratımlarından teyit etmiştir.

Paul Klee, rengi bir nitelik olarak alır. Renkler birbirlerinden nitelikleri ile ayrılırlar. Renkleri ölçmeye ne kural ne de ölçüm cihazı vardır. Örneğin, özdeş büyüklük ve parlaklıkta olan sarı ile kırmızı ölçü ve ağırlık bakımından ayrıştırılamazlar. Fakat sarının daha ışıklı olması onu kırmızıdan ayırmaya yeterlidir. Şeker ile tuz birbiri ile karşılaştırılabildiği gibi renkler de genişlik ve ağırlık niteliğine göre karşılaştırılabilirler. Bu noktada renklerin parlaklığı ve yoğunluğu ölçülebilir. Klee, altı renkten meydana getirdiḡi renk çemberinde birincil ve ikincil renkleri tamamlayıcıları ile karşııklı eşleşen düzen içinde konumlandırmıştır (Klee,1987:19-20). Resim çalışmasında sezgisel renk düzenlemelerine girişmiş̧tir. 'Sihirli Balık' resmi iki temel kontrast üstüne kurulmuştur. Illki açık mavi, pembe ve turuncu renkler arasındaki açık-koyu kontrastı, ikincisinde ise kırmızı ve koyu mavinin arasındaki yoğunluk kontrastıdır (Itten, 2004: 102).

\section{Bilimden (Fizik, Fizyoloji, Görsel Algılama) Sanata Evrilen Teoriler ve Resim Sanatına Etkileri}

Sir Isaac Newton, 1704'de yayınlanan 'Optics'te (Optik), 'Işığın Parçacık Teorisi'nde rengi fiziksel bir oluşum olarak ele almış ve ışı̆̋ın küçük parçacıklardan meydana geldiğini savunmuştur. Prizma deneyinin birinde ışı̆̊ın belli dalga boyları arasında sırası ile kırmızı, turuncu, sarı, yeşil, mavi, indigo ve mor olmak üzere yedi renge, ayrıştığını; ikinci deney de tam tersine tüm renklerden tekrar beyaz ışığı elde ettiğini göstermiştir. Buluş, sanatçılar arasında hayretle karşılanmıştır. Bazı renklerin karışım yoluyla oluştuğu bilgisi aynı deneyin bir başka sonucudur. Renk karışımı meselesi, yani iki rengin karışımıyla yeni bir rengin ortaya çıkması, renk görme konusunda düşünmenin kapsamını genişletmiştir. Bu konuda; Newton'dan başka Brewster, Young-Helmholtz, Hering, Ladd Franklin ve Chevreul'un Teorileri bulunmaktadır.

David Brewster, 'Renk Görme Teorisi'nde kırmızı, sarı ve maviden oluşan üç temel ışık rengi bulunduğunu ve bunların değişik oranlarda karıştığında diğer tüm renk ışınlarının elde edileceğini kabul eder. Bunu bir daire içine çizdiği eşkenar üçgenin uç noktalarını sarı, kırmızı ve maviye boyayarak gösterir. Ters çizilmiş ikinci bir üçgen ile renkleri ikişerli halde eşleştirip karıştıır ve bulduğu karışım renklerle bu kez ters üçgenin uçlarını boyar. Her bir rengi kendisini meydana getiren iki renk arasında olacak şekilde konumlandırır. Üçgenlerin meydana getirdiği altıgen şemaya göre; karşı।ıklı gelen renkler birbirinin tamamlayıcısıdır (Çağlarca, 1993: 16).

Thomas Young'un 'şı̆̊ıı Dalga Teorisi', Von Helmholtz tarafından geliştirilmiştir. 1801'deki metinde; "Retinada tasarlayacağınız kadar belirsiz sayıda renk zerrecikleri bulunması ve her cins ışık dalgası etkisi ile bunların harekete geçip dalgalanmaları ve belirli sayıda kırmızı, sarı ve mavi gibi ana renklerden düzen kurmaları gerekmektedir" diye yazar (Gregory, 1972: 118; Akdeniz, 1982: 32'den).

Young, yaptığı deneylerde kırmızı ve yeşil ışık karışımının sarı olduğunu gördüğü için, gözde sarı renk için özel bir toplayıı hücre tipi olamayacağını ileri sürmüştür. Buna göre, algılamada sarı renk duyumu, iki tip toplayıcı hücrenin birbirini tamamlayan çalışmaları sonucu gerçekleşmiş̧ir. Young, ayrıca yoğunlukları tamamen farklı üç ayrı renkli ışık; kırmızı, yeşil ve mavi-mor karışımıyla diḡer spektral renklerin oluşabileceğini ve bu üç rengin karışımlarının beyazı verdiğini iddia etmiştir. Bu nedenle gözün, temel üç renge duyarlı olduğunu savunmuştur (Akdeniz,1982: 33).

Young'un rehberliğinde Helmholtz tarafından geliştirilmiş ve bugün 'Young- Helmholtz Kurami' olarak bilinen 
Renk Görme Kuramı: "gözde üç tip renge duyarlı toplayıcı hücre olduğunu kabul eder. Bu üç toplayıcı hücre tipi kırmızı, yeşil ve maviye duyarlıdır ve bütün öteki renkler bu üçlü sistemin renk sinyalleri karışımı ile görülebilir" (Kaufmann, 1974: 159; Yazıcıoğlu, 1990: 107'den). Burada ele alınan hücre tipi renkli görmeyi sağlayan konlardır. Renksiz görmeye hizmet eden konik hücreler ise ışıksız ortamda işlev görürler.

Helmholtz, boya ve ışık renklerde karışımla elde edilen renkler arasında meydana gelen farkların nedenini kanıtlamıştır. Helmholtz, aynı merkezli iki daire çizerek dıştaki daireyi dörde bölüp çıkan alanları karşılıklı olarak sarı ve maviye, orta kısmı da sarı ve mavi boyaların karışımından elde ettiği yeşil renk ile boyar. Daireyi hızla döndürerek dıştaki dairede sarı ve mavinin optik karışımını, yeşil değil beyaza yakın bir gri olarak gözlemler. Sebebi, bu iki rengin birbirinin tamamlayıcısı olmasıdır. Karıştırıldıklarında birbirinin renk gücünü düşürürler. Makyevel benzer şekilde, ışık renkleri üstüne yaptığı deneyde; Sarı ve mavi ışık ile aydınlattığı diski çevirerek ne yeşil ne de yeşile benzer hiç bir rengi vermediğini; boya renklerde elde edilen karışımın, renkli ışınlarla elde edilmediğini görmüştür (Çağlarca, 1993: 15).

Tam anlamıyla Hering'in tarif ettiği ardı ardına kontrastlık fenomeni, tamamlayıcı renkler arasında gerçekleşir. Hering'in tamamlayıcı renk çiftleri arasında yaptığı deneylerde, renkli bir levha, birkaç dakika izlendikten sonra yerine konan gri ya da beyaz bir levhada, önceki izlenen rengin, göz retinasında meydana gelen kontrastı, görmenin fizyolojik işleyişinde, hayali olarak görülür. Örneḡin bakılan renk kırmızı ise hayali görülen renk yeşildir. Aynı durum, sarı-mavi, siyah-beyaz kontrastlığı için de geçerlidir (Tunalı, 1983: 75).

Chevreul, Helmholtz ve Rood'un geliştirdikleri 'Eş Zamanlı Renk Kontrastları Yasası'nda; rengin üç niteliği: yoğunluk, tür ve ışık değişime uğrar. Renkler arasındaki ilişkilerde eş zamanlı olarak renk alanlarının oranları, rengin açık koyu değeri, parlaklığı veya renklilik yönü etkileşime girer. Etkileşme zıt renkler arasında en üst seviyededir. Örneğin ışık miktarı aynı olan yeşil ve kırmızının kontrastında bu iki renk, yan yana gelince birbirlerinin renk yoğunluklarını arttırma yönünde etkilerler. Renkler karşııklı olarak güçlenir; yoğunlukları artar. Ama aynı ışı miktarına sahip oldukları için ışıklılık yönleri deḡişmez. Boya olarak karıştırıldıklarında ise birbirlerini yok ederek renklilik yönü nötrleşmeye doğru gider. Etkileşim herhangi iki renk söz konusu olduğunda da gerçekleşir. Yeşil ve mor yan yana kullanıldığında yeşilin kontrastı kırmızı, moru daha da kırmızılaştııır; morun kontrastı sarı ise yeşili daha da sarartır. Morun yeşile göre daha ışıklı olması etkileşimi ışık boyutuna da taşır. Yeşil morun yanında daha açık değerde algılanır. Ya da tam tersine mor yeşilin yanında daha koyu deḡere bürünmüş olarak görünür. Bu renklerin her ikisinde bulunan ortak renk mavi, renklerdeki mavi yoğunluğunu azaltır (Sérullaz, 1983: 16). Bu yasalarla resimde var olan renk yokmuş gibi, yok olan ise varmış gibi algılanabilir.

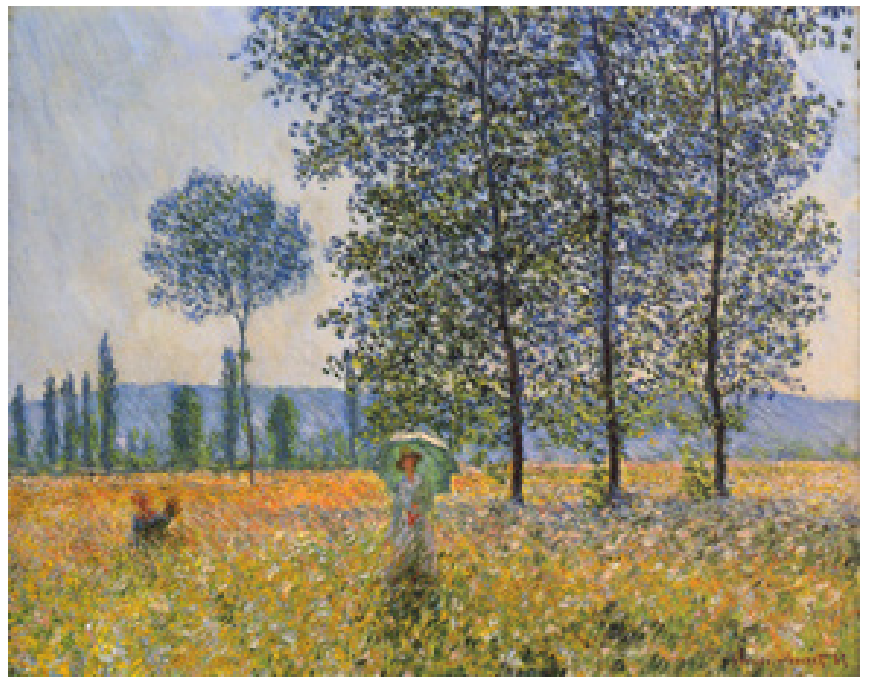

Resim 6. Claude Monet, 'ilkbaharda Tarlalar',1887 Tuval Üzerine Yağlıboya, $74.3 \times 93 \mathrm{~cm}$. Devlet Müzesi, Stuttgart

Claude Monet 'nin (1840-1926) 'ilkbaharda Tarlalar' adlı resmini (Resim 6), sarı ve mavi alanlara bölmesi ile Eş Zamanlı Kontrast yasalarında belirtilen durum gerçekleşir; Mavi gökyüzü fonunda ağaçlar, yeşil olduğu halde bu kontrastlık fenomeninin etkisiyle sarımtırak görünür. Ağacın sarı alana düşen gölgesi morumsu mavi olarak algılanır. Ağaçlardaki yeşil renge kontrast yapması için alt planda küçük alanlar kırmızı ile boyalıdır (Çağlarca, 1993: 63-64).

Ressamların paletlerine canlı renkleri katmalarında, kendinden önceki tecrübelerin katkısı elbet bilinmektedir. Fakat söz konusu deg̃işimin ressamların doğaya açılmalarıyla doğrudan ilgisi vardır. Bundaki başlıca etmen 
ise şüphesiz Aydınlanma çağıdır. Hem bilim hem de sanat dünyasının yüzünü doğaya döndürmesidir. Sanatçılar için daha da önemlisi doğaya tüm yargılardan uzak, özgürce tarafsız bakabilmektir. Bunu başardıklarında Newton'un renk tayfını doğada görebilecek ve sanatında göstereceklerdir. Ancak Newton'un keşfettiği yedi rengin, prizmadaki parlaklığı ile sanata yansıması, iki yüzyıldan daha fazla sürenin geçmesini gerektirmiştir. Çünkü bilimsel bilginin sanata evrilmesi sanat beğenisinin değişmesi; birbiri içinde gelişmiş sanat bilgisinin ve mantık dizgesinin de yıkılması demektir. ilerleyen süreçte sanatçılar, Leonardo da Vinci'nin (14521519), ve Newton'un daha önce fark ettiği şeyi, Helmholtz ve Chevreul'un Optik yasalarından, güneş ışı̆ı̆ıı prizmatik olarak kavrayarak nesneleri çevreleyen ışık ve havanın konturları erittiğini; renkleri sürekli değiştirdiğini öğrendiler. Işık ve dolayısı ile renk, bu sayede resmin temel konusu oldu. Doğa gözlemlerinde bilimin çerçevesinde ressamlarca incelendi. Işık ve rengin meydana getirdiği bu dünya değişen titreşen ve oluşum halinde bir dünyadır. Bu görünen dünya geleneksel yöntemlerle, değişmez ışık ve renk lekelerinden meydana getirilemezdi. Çünkü doğada, renkler belli yasalara göre, belli şekillerde dağılmaktadır. Bunların başında renk karşıtlığı ile ilgili yasalar gelmektedir. "Eğer, bilimsel olarak, sanat tecrübesiyle resimde rengin kurallarını bulabilmişsem, benzer şekilde, resmimin çizgilerini ahenkli hale getirmeme izin verecek biçimde resme ait bilimsel ve mantıklı bir sistemi ortaya çıkaramaz mıyım?" diye soran Seurat, resmin renkle olan geleneksel ilişkisinin artık sürdürülemeyeceğini ilan etmiştir (Gage, 2005: 247).

Bilimsel renk teorilerinin estetikle ilişkisi doğa ile doğrudan temas kuran Empresyonistler ve Post Empresyonistler ile birlikte 19. yüzyıl sonlarında görülür. Bu ressamlar, rengin boya maddesi olarak bilimsel anlamda ışıkla ilişkisini araştıııken alışımadık bir biçimde rasyonel tekniklerle renk karışımlarında gün ışığını ele geçirdiler. Doğal sonuçlara ulaşmak için bilimsel ve sanatsal bilginin potasında gelişmiş tamamlayıc kontrastık yasasının yanı sıra ardı ardına kontrastlık ve eş zamanlı kontrastlık yasalarını renk kullanımına aktardılar. Ortaya çıkan sanat yapıtında doğadaki ışık, genellikle prizmatik olarak parçalar halinde resim yüzeyinde renge dönüşmüştür.

Empresyonistler anı yakalamak isterken deḡişen ışıkla birlikte dış dünyanın, nesnelerin rengi ile beraber yapısının da değiştiğini gördüler. Akıp giden zaman içinde nesnel görünüm sürekli değişim geçirmektedir. Form, üzerine düşen ışığın geliş açısı oranında ve çevresindeki diğer biçimlerden gelen yansımalarla an be an nitelik ve niceliksel değişime uğratılmaktadır. Lokal renk, değişen ışık altında çevreden gelen yansımalarla ve doğanın atmosferik etkisi ile değişir ve biçimsel görünümün sınırları yumuşar. Böylece tuval yüzeyinde keskin hacim illüzyonundan çok renk alanlarının titreşimi ile renk espasları oluşur. Bu oluşumlar, bilimsel renk bilgisine dayalı boyama yöntemindeki yenilikle, resmin tüm yüzeyine ışığın homojen yayııması ile sağlanmıştır. Resim yüzeyine çarpan gün ışığı, fırça tuşlarıyla sabitlenmiş, küçük renkli alanların gözde karışımı ile beyinde bir duyum olarak renk alanlarına dönüşmüştür. Empresyonizmde açık havaya, güneşe temas eden ressam, doğayı süreç içinde gördüğünden şekli bir tarafa bırakıp farklı anları, değişik duyu ve izlenimlerini ışık ve renk yüzeyleri halinde tuvale tespit etmiştir. Ressamın izlenimi resim diline çevrildiğinde bile ışık ve renk duyumu doğadaki gibi gerçektir. Doğada meydana gelen optik oluşumlar resim yüzeyinde de gerçekten oluşmakta ve görülmektedir (Tunalı, 1983: 53-54).

Renk alanlarını biraz daha geniş ölçekteki komşu tonlarla meydana getiren Paul Cézanne (1839-1906), bir yandan nesnelerin yığın olarak oluşturduğu kütlelere hacim etkisi kazandırırken diğer yandan karşıt ton ilişkileri ile resim düzlemini hissettirmektedir. O'nun resminde tamamlayıcı renklerin eş zamanlı kontrastlık içinde algılandığı durumlarda; renk alanlarının bitişik kenarlarında rengin gerçekte olmayan kontrastını üretmesi, atmosferik etkinin oluşumuna yardım eder. Fakat, komşu tonlarda bu etki bu denli kuvvetli oluşmadığından, birbirine yakın renk tonalitelerinin resim düzlemindeki kapladığı alanlar boyunca, geniş kütleler halinde hacim duygusunu yansıtmıştır. Resmini sağlam bir biçimsel temele dayandırmak isteyen Cézanne, amacını geliştirdiği renkli modülasyon sayesinde gerçekleştirmiş resim dilinde yeni ve parlak armoniler yakalamıştır. Itten'e (2004: 15) göre, "Cézanne için bir rengi modüle etmek soğukla sıcak, açıkla 
koyu veya sönükle yoğun arasında varyasyonlar yaratmak demektir ". 1904'te Bernard'a yazdığı bir mektupta resimlerinde (Resim 7) derinliği nasıl elde ettiğini şöyle anlatmıştır: "Doğa yüzeyden çok derinliktir; kırmızılarla, sarılarla temsil edilen ışık titreşimleri içine mavi katılması, derinlik izlenimini uyandırmak içindir" (Antmen, 2008: 28).

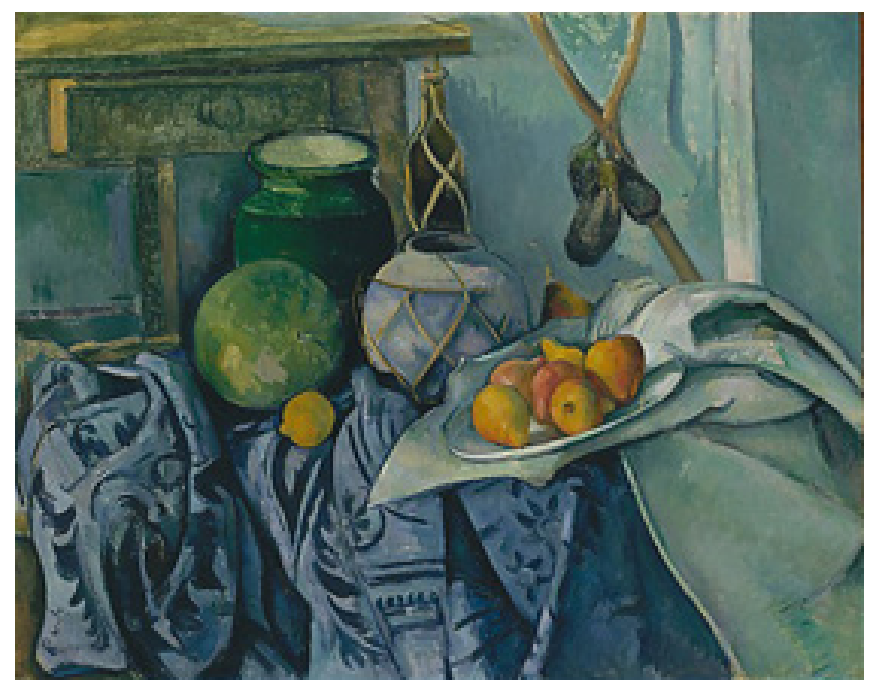

Resim 7. Paul Cézanne, 'Zencefil Kavanozlu ve Patlıcanlı Natürmort',1893-94 Tuval Üzerine Yağlıboya, 72.4 x 91.4 cm. Metropolitan Sanat Müzesi, New York

Cézanne gibi adı 'Post Empresyonist' ressamlar arasında anılan Paul Gauguin (1848-1903), renk ve biçim tavrında görünen dünyaya bağlılı̆ı aşarak doğrudan doğadan çalışan empresyonistlerden ayrilır. Resminde simgesel, dekoratif ögeler ve anti-natüralist renk kullanımı ile dikkat çeker. Sanatın bir soyutlama olduğu görüşündedir. Buna ulaşmak için de çok fazla doğadan çalışmamayı, ancak, doğadan yola çıkmayı, doğa önünde hayal kurmayı ve resmin kendisine odaklanmayı tavsiye etmiştir. Gauguin'in öncüsü olduğu Fovizm'in temsilcilerinden Henri Matisse (1869-1954), anti-natüralist renk anlayışında eserler vermiştir Az sayıda renkle zengin ve ritmik armoniler yaratmıştır (Antmen, 2008: 26-30).

Neo-Empresyonistlerin kesin kuralları ve akla dayalı yöntemleri vardı. Onlar tamamlayıcı renk çiftlerini Chevreul'ün yetmiş iki bölümlü renk diyagramına göre seçip kullanıyorlardı. Herhangi bir kırmızı, herhangi bir yeşilin kontrastı olamazdı. Eğer mora çalan bir kırmızı ise yeşil, daha fazla sarı içermeliydi. Kırmızı turuncuya dönükse seçilen yeşil, maviye bakmalıydı (Sérullaz, 1983: 22-23).
Neo-Empresyonistler renk alanlarını daraltıp noktacıklara indirgeyerek kontrastlık etkisini tüm bu kriterlerin ötesine taşıyacak olan sanatsal bir tekniği keşfetmişlerdir. Noktacılık denen bu tekniğe göre renkler, optik olarak gözde karışır; parlak renk noktacıkları biraz aralıklarla tuval yüzeyini az gösterir şekilde yan yana getirilir ve renkler doğada göründükleri değerde oluşturulurdu. Georges Seurat (1863-1935), Paul Signac (1863-1935), Camille Pissarro (1830-1903), ve oğlu Lucien Pissarro (1863-1944), kullandıkları bu yeni teknikle renk teorilerine doğal sonuçlar için başvurmuştu (Resim 8). Çok ilginçtir ki, Neo-empresyonistler, bu teknikte spektral renkleri kullanmalarına rağmen dış dünyayı temsile dayanan tavrı sürdürüp doğal etkilere ulaşmışlardır. Bu gerçekten de geleneğin o kompleks yapısını terk etmenin zorluğuna işaret eder.

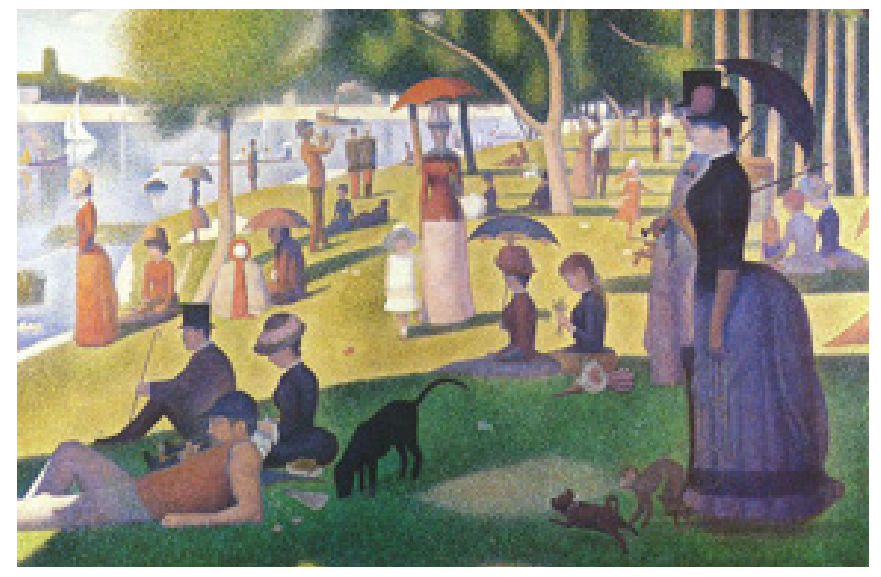

Resim 8. Georges. Seurat, 'Grande Jatte Adası'nda Bir Pazar Öğleden Sonrası', 1884-86 Tuval Üzerine Yağlıboya, $207.6 \times 308$ cm. Şikago Sanat Enstitüsü

Harrison ve Wood'un, 'Sanat ve Kuram' (2011) adlı kitabında yer verilen, Signac'a ait makaledeki saptamalar bu fikri desteklemektedir. Neo Empresyonistler, saf optik renklerin karışımı sayesinde elde edilen parlaklık ve çeşitli tonlarla yetinmezler. Bu teknik, eserin bütün uyumunu öğelerin oran ve dengesine dayanarak, kontrast, gölge ve ışık kurallarına bağlı olarak sağlar. Empresyonistlerin nadiren ve içgüdüsel olarak gözlediği bu kurallara, Neo Empresyonitler ciddiyetle uymuştur. Onlara göre bu duyumu güçsüz bırakmayıp ona rehberlik eden koruyan kesin ve bilimsel bir yöntemdir Neo Empresyonistler, sanat tarihinde cesur renkleri ile bilinen Delacroix’nın öğüdüne uyan bir şekilde şöyle hareket 
ederler: Bir tuvale kompozisyonu tamamlamadan başlamaz. Gelenek ve bilimin rehberliğinde, kompozisyonu düşüncesiyle uyumlu hale getirip; çizgi, ışık ve gölgedeki renkleri, varmak istediği etkiye uydururlar. Dinginlik için yatay, neşe için yükselen, üzüntü için inen çizgileri seçerler. Ara çizgiler sonsuz çeşitliliğe sahip bütün diğer duyumları tasvir etmek için kullanılacaktır. En az onun kadar dışavurumcu ve çeşitli olan çok renkli etkileşim, bu çizgi etkileşimine katılır; yükselen çizgilere karşılık olarak sıcak renkler ve açık tonlar yer alır; inen çizgilere, soğuk renkler ve koyu tonlar hakim olur; sıcak soğuk renkler, soluk ve yoğun tonlar dengesi yatay çizilerin dinginliğine eklenir. Böylece renk ve çizgiyi, hissettiği ve çevirmek istediği duyguya boyun eğdiren ressam, bir şair, bir yaratıcı rolünü görür (Harrison ve Wood, 2011: 37'den).

20. yüzyıl sanatçıları aynı teorileri soyuta ulaşmak için kullandılar. Fransız Optik Teorileri rengi özgür bırakmanın yollarını arayan birçok sanatçıya önemli bir kaynak sağlamıştır (Moszynska, 1993: 15). Renk teorilerini kendi amacını gerçekleştirecek şekilde ele alan Çek ressamı Frantisek Kupka (1871-1957), saf renk soyutlamalarına girişen ilk sanatçıydı. Resimleri Orphik Kübistlerle ilişkilendirilen sanatçının deneyimleri, 1896'da yerleştiği, Paris'te 1911 yılının ilk zamanlarında başladı. 1910-11' e tarihlenen el yazısı notlarda, kavisli ve düz çizgilerin, dikey düzlemlerin resimsel olanakları hakkında yazdı. Teknik uygulamaların desteği ile doğa kökenli türetilen konuyu veya zihinde tasarlanan hayali motifleri görmezlikten geldi. Kupka, rengi anlatımcı işlevinden kurtararak hareket devinimi önermek için tek başına rengin gücünü araştırdı. Kırmızının dalga boyunu dikkate aldı, Rengin derinlik etkisinin az, yoğunluğunun düşük olmasını önemsedi (Resim 9).

Bir diḡer Fransız Orphik Robert Delaunay (1885-1941), 1905-07 yılları arasında, Chevreul'un tezi, 'Eş Zamanlı Renk Kontrastlıkları ilkesi (1839)' üzerine, çalışmalar yaptı. Delaunay, Chevreul'un prizmatik ve tamamlayıcı renkler üstüne optik analizleri ve benzer şekilde Rood'un ışığa maruz kalan açık havadaki ayrı renk karışımlarını tanımladığı iki teorik bilgiden ve Kübizm' den yola çıktı. Teknik açıdan renk ve renk kontrastlıklarına dayanan, hem eş zamanlı algıya bağlı kendi düşüncesini önereceḡi hem de zamanı dahil edeceği resim yapma fikrini geliştirdi. Delaunay, Chevreul'un renklerin eşzamanlı kontrastlık ilkesine bağlı olarak yoğunlaştığı bilimsel renk düşüncesini sadece biçim değil, aynı zamanda hareket illüzyonu ifadesiyle de genişletti. Soyut resimde bu düşünce içinde yaratılabilecekti. Delaunay bir dizi resminde bu düşüncelerini şekillendirmeye başladı. 'Pencereler' serisi (1912) var olan görüntüyü tasvir etmekten daha çok ışık oyunlarına ilgisini gösterir. Dolayısıyla aynı anda açılan pencerelerde Eiffel kulesinden artakalan göndermeler sadece üçgen şeklindeki yeşil düzlemlerde izlenebilir. Pencereye dair görünümün arkasında prizmatik parçalarda bir yandan diğer yana oval simetrik eğriler yayılır. Resme bakış, gözün resim yüzeyinde öte-beri hareket etmesi, renk, ton ve biçimin hoşa gidecek şekilde karşılıklı ilişkisi içinde belirlenir. Delaunay 'Pencereler' serisine eşlik eden metinde, doğadaki ışığın renkteki hareketi oluşturduğunu, yazmıştır. Hareket, renklerin kendi aralarında farklı ölçülerdeki kontrastlık ilişkilerinden sağlanır ve zıt renkler arasındaki ilişki bu gerçekliği oluşturur. Bu seriye benzer şekilde rengin ve ışık etkileşimlerinin öne çıktığı 'Güneş ve Ay' serisindeki resimlerinde, ağırlıklı olarak dairesel biçimlerden daha keskin veya gerçek olduğuna inandığı optik etkileri ele geçirmeye yönelik artan ilgisi görülmektedir. Renklerin etkileşimi, dogal dünyayı referans almadan derinlik ve hareket hissi üretir (Resim 10).

Stanton Macdonald-Wright (1890-1973) ve Morgan Russel (1886-1953) adlı Paris'te yaşayan iki Amerikan sanatçı Delaunay ve Yeni Emresyonistlerin de ele aldığı aynı bilimsel renk çalışmalarına dayanan 'Sinkronizm' adıyla bilinen renk teorisini geliştirdiler. 'Sinkroni' adı, müzikteki Senfoni kelimesi ile sessel ilişki bakımından renklerle sağlanan ritmi ima etmek için seçilmiştir. Russel, Rubens ve Michelangelo'nun biçime uyguladığı kıvrım ve spiralleri renkle elde etmek istemişti. 'Işık için Renk Birliği' çalışmasındaki eğik biçimlerin Michelangelo'nun ölen kölesi için yaptığı eskizlerle ilgisi vardır. Tamamen soyut olan ilk Sinkroni resmi, Morgan Russel'ın 'Koyu Mavi Menekşede Birlik' adlı çalışmasıdır (Resim 11). Macdonald-Wright'ın 1915 tarihli 'Sinkroni Kavramı' adlı resmi (Resim 12), Kupka'nın diskleri ve Delaunay'ın renklerle yakaladığı dalgalanmalara benzer etki yakalamıştır 


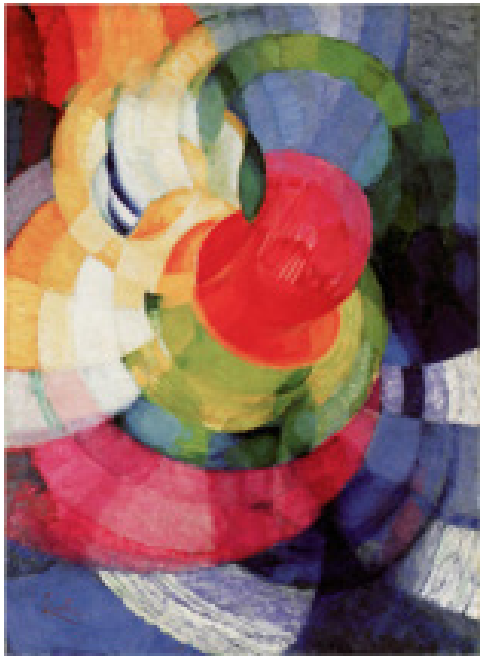

Resim 9. Frantisek Kupka, 'Newton Diski', 1911 Tuval Üzerine Yağlıboya, $77.5 \times 73.6 \mathrm{~cm}$. Philadelphia Sanat Müzesi

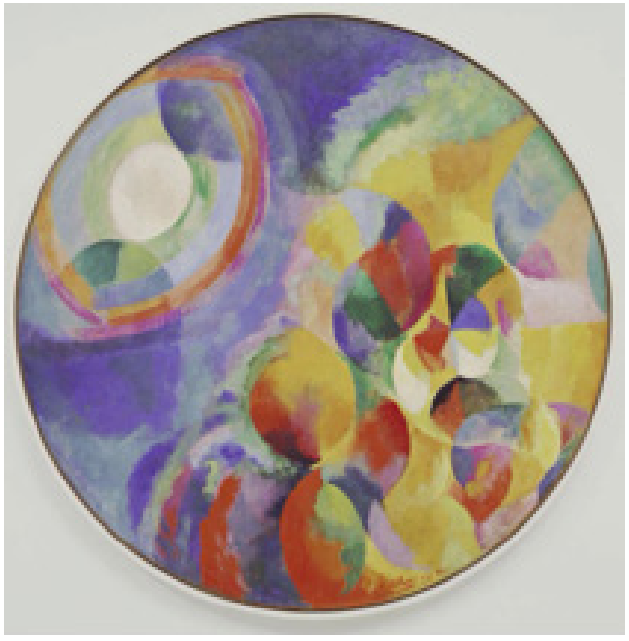

Resim 10. Robert Delanuay, 'Güneş ve Ay', 1912

Tuval Üzerine Yağlıboya, Çap:134.5cm. MoMA

Bazı İtalyan Fütüristlerinde bilimsel teorilerin etkisi, renkleri temsil edici fonksiyonlarından koparıp özgürleştirme şeklinde yansıma bulur. Onlar da renk teorisini kendi amaçlarına yardım edecek şekilde dönüştürdüler. Gino Severini (1883-1966) Paris ve Milan arasındaki bağların kurulmasında önemli rol oynadı. Zaten, İtalya'da, Fransız Neo Empresyonist'lerin kullandığı Divizyonizm tekniğine ilgi vardı. Bu yıllar boyunca Severini, Bilimsel yöntemle resimdeki saf renk çeşitliliğini, bölünmüş dengelenmiş ve karıştırılmış optikselliği içeren Divizyonist teori hakkında, kendi bilgilerini arttırmak ve ilk elden örnekleri incelemek için Paris'ten yeni izlenimci Paul Signac ile iletişimde olmuştur. Severini
Divizyonist tekniği kullanmış ve hatta pigmentlerin tablo üzerindeki sürekliliğini amaçlayan Neo izlenimci tavrı (Resim 13) sürdürmüştür (Moszynska, 1993: 16-18).
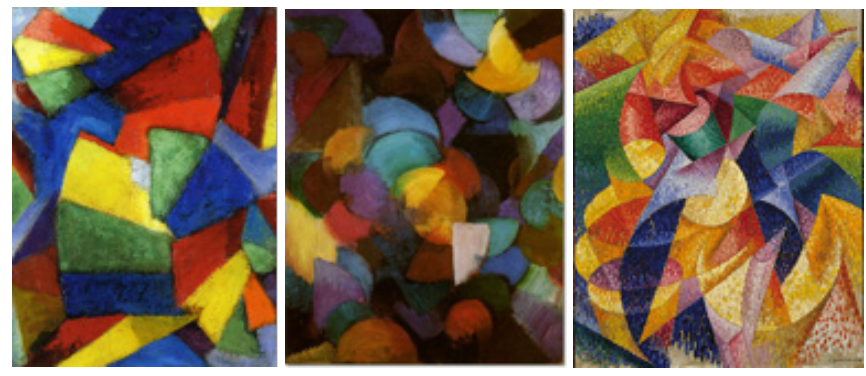

Resim 11. Morgan Russel, 'Koyu Mavi Menekşede Birlik',1913 (Sol) Tuval Üzerine Yağlıboya, 33×24.4cm. Rose Fried Galeri, New York.

Resim 12. Macdonald Wright Stanton,'Sinkroni Kavramı' 1915 Tuval Üzerine Yağlıboya, $76.2 \times 61 \mathrm{~cm}$. Amerikan Sanatı Müzesi, Whitney

Resim 13. Gino Severini,'Dansçı,'1914 (Sağ)

Tuval Üzerine Yağlıboya, 105.3x85.9cm. Peggy Guggenheim Kolleksiyonu, Venedik

Bilimsel bilgilerle renklerin eş zamanlı etkilerinden yararlanarak titreşim, devinim ve hareket duygusunu verenler yalnızca empresyonistler değildir. Aynı teorilerden hareketle yeni etkilere ulaşanlar Op Sanat'çılardır. Bu sanatçılar, renk, çizgi ve soyut biçimlerle optik etkinin gerçekleşmesi üstüne yoğunlaştılar. Tamamlayıcı kontrastların yan yana kullanımı ile renklerin birbirini eş zamanda en üst derecede etkileme gücünden oluşan optik yanılsamayı fark ettiler. Yapıtlarında Hering yanılsaması diye bilinen, birbirine çok yakın çizgilerin farklı açılarda üst üste gelmesi ile kesişme noktalarında oluşan görsel yanılsama etkilerini kullandılar. Op Sanatçılar, renk ilişkilerini ardı ardına ve eşzamanlı kontrastlık fenomenleri çerçevesinde sistemleştirerek 1955-65 yılları arasında, optik yanılsama etkilerini daha da vurgulayan yeni bir sanat dilini, 'Optik Sanat/Op Art'ı yarattılar. Resim sanatı kendiliḡinden yanılsamaya dayalı olmasına rağmen, Op Sanat, bilinçli olarak algı yanılsaması yaratmak üzere algıyı yönlendiricidir. Normal algı süreçlerini işletmek, optik fenomenlerden yararlanma ve doğrudan algı yanılmasına dayalı olduğundan bilinci ve bilinçaltını etkileme gücüne sahiptir. Op yapıt herkese seslenir. Sanat konusunda donanım gerektirmez. Fark edilmesi için bu tip üretimlere 
sadece bakmak yeterlidir. Özellikle tüketimle ilgili şeylerde grafik sanatlarında Op sanattan sıkça yararlanılması bu özelliginden kaynaklanır. Rudolf Arnheim' in (1904-2007) Art and Perception: A Psychology of the Creative Eye (Sanat ve Yanılsama: Yaratıcı Gözün Psikolojisi) adlı, 1954 basımı kitabı algı yanılsaması konusunda Op sanatçılarına kaynaklık etmiştir.

Lucia Fontana (1899-1968) ve Victor Vasarely (19081997) uzam araştırmalarında; Josef Albers (1888-1976) renk çalışmalarında, figüratif olmayan, görsel yanılsamalar yaratmak ya da algılamayı bozan etkiler yakalamak için belli bir kurgulama mantığı ile matematiksel dizge çerçevesinde sistematik olarak düz boyalı renk alanları, geometrik biçimler, çizgi ve nokta gibi sanatın yapı taşlarını kullanmışlardır. Optik yanılsamalar, dinamik etkiler üreten sanat tavırlarının ortaya çıkmasında rol oynamıştır (Resim 14). iki boyutlu yüzey üzerinde gerçek olmayan hareket, üç boyut, uzak/yakın, derinlik veya mekan değişimleri yaratmıştır (Tuğal, 2012: 94-97).

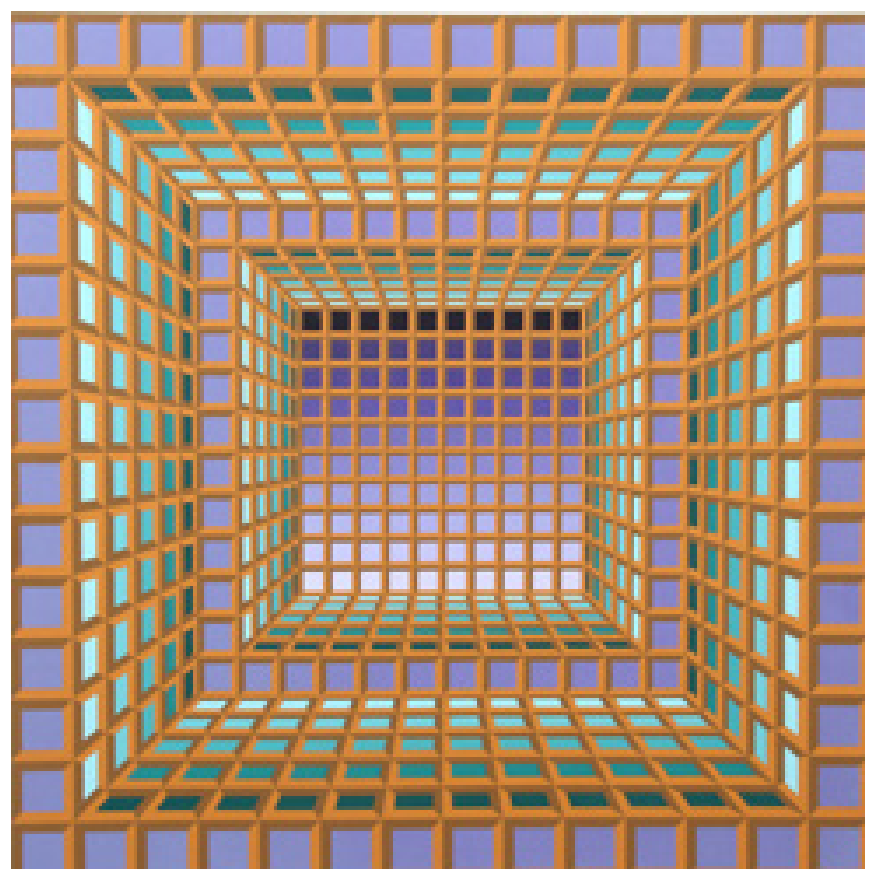

Resim 14. Victor Vasarely, 'Mor İçinde Çok katlı Izgara', 1970,

Serigraf baskı-26/250, 81.28×76.2 cm. Ro Galeri, New York

Sanat anlayışını 1950 öncesi 'hisset ve yap', 1950 sonrası ise 'tasarla, ifade et ve ortaya çıkar' şeklinde tanımlayan Vasarely biricik sanat yapıtının ortadan kalkacağını ve sanatın makineler yoluyla üretileceğini söyler. Onun geliştirdiği sanat tekniği, bugün en mükemmel şekilde teknolojinin olanakları ile üretilebilecek ve çoğaltılabilecek türdendir.

\section{Sonuç}

Batı sanatının renk hakkında evrimi sanatçıların kendinden önceki ressamlardan etkilenmeleri ya da sadece doğaya çıkmaları ile açıklanamaz. Bu konuda bilimsel verileri de dikkate almak gerekir. Renk görme ve algılama hakkında tüm bilimsel çalışmalar, rengin bir duyum olarak algılanmasını sanata kazandırmıştır. İtten'e göre Bilim dünyasında kimyasal ve fiziksel olarak analiz edilebilen renk, boya maddesi olarak sanat dünyasında görüş ve zihinsel algılama ile insanda anlam ve içerik bulmuştur.

Sanatçılar tarih boyunca sağlam biçimlere ulaşmak, kompozisyon ve estetik yapıyı oluşturmak için renk ilişkilerinden yararlanırlar. Bilimsel çalışmalarda bu renk ilişkileri yasalarla açıklanmıştır. Rengin yapısı, oluşumu, görülmesi, algılanması, anlamlandıııması ve kullanımını kapsayan çalışmalar, Fizik, Fizyoloji, Kimya, Biyoloji, Psikoloji ve Sosyoloji gibi bilim dalları ile Sanat arasında bilgi alışverişini doğurmuş, 17. yüzyıldan bugüne geçerliliği hala devam eden renk teorilerini sanata kazandırmıştır.

Çalışmalarını renk odaklı gerçekleştiren ressamlar, renk ilişkilerini Hering, Helmholtz ve Chevreul'un kontrastlık teorilerinden yararlanarak düzenlediler. Renk karışımlarında optik kuralları uyguladılar. Bu ilkenin sanatçılarca kavranmaSı, renklerin birbirini etkileme gücünü kullanmalarını sağladı. Bu istedikleri etkiyi rastlantı ve aramalarla değil bilerek elde edebilecekleri anlamına geliyordu. Sanatçı bu bilgiler ile renkleri ekonomik olarak parlak, mat veya en çarpıcı bir biçimde gösterme becerisine erişmişti. Renk teorilerinin katkıları ile renkleri bir arada kullanmanın uyumu kontrastlık ilişkileri içinde çözümleniyordu.

Önceleri resmin biçimsel ögesi konumunda olan renk, eşyanın/maddenin bir özelliği ya da sembolik bir anlam olarak değerlendirilirken; Renk hakkındaki bilimsel çalışmalar, sanatçının rengi bir duyum olarak algılamasını sağladı ve renk pratiklerinde biçimden bağımsızlaşıp salt görsel olana yönelmesinde; sanatta illüzyonun kırılmasında rol oynadı. 
Renk resmin içerikle ilgili ögesi haline geldi. 19. yüzyıl sonlarından itibaren sanatçılar, renk ilişkilerinin başlıca içerik olduğu estetik deḡerler yarattılar. Renkleri bir düzen içinde konumlandırıken aynı zamanda bilimsel bilginin verilerini sanatta doğal sonuçlara veya soyuta ulaşmak için kullandılar.

\section{Kaynakça}

Akdeniz, Halil (1982). "Görsel Algılama Açısından Renk Kullanımı ve Etkileri”, Yayınlanmamış Yüksek Lisans Tezi, İzmir: Ege Üniversitesi Biçimsel Sanatlar Bölümü.

Antmen, Ahu (2008). 20. Yüzyıl Batı Sanatında Akımlar, İstanbul: Sel Yayıncılık

Crary, Jonathan, (2004). Gözlemcinin Teknikleri: 19. Yüzyılda Görme ve Modernite Üzerine, Çev. Elif Daldeniz, İstanbul: Metis Yayınları.

Çağlarca, Sadettin (1993). Renk ve Armoni Kuralları, 4. Baskı, İstanbul: İnkılap Kitabevi Yayınları.

Farago, Frango (2006). Sanat, Çev. Özcan Doğan, Ankara: Doğu Batı Yayınları.

Gage, John (2005). Colour and Culture, Singapur: Thamas\&Hudson

Goethe, John Wolfgang Von (2013). Renk Öğretisi. Çev. Illknur Aka, İstanbul: Kırmızı Yayınları.

Gombrich, Ernst Hans (1992). Sanat ve Yanılsama, Çev. Ahmet Cemal, İstanbul: Remzi Kitabevi.

Gregory, L. Richard (1972). Augo und Gehim zur Esychophysiologie des Sehens, Frankfurt am Main: Verl. Fischer Taschenbuch.

Harrison, Charles ve Wood, Paul (2011). Sanat ve Kuram Değişen Fikirler Ontolojisi, Çev. Sabri Gürses, İstanbul: Küre Yayınları.

Itten, Johannes (2004). The Art Of Color, Ing.Çev. Ernst van Haagen, NewYork: John Wiley\&Sons, Inc.

Kamıs, Ümit; Okka, Mehmet; Küçükçelik, Hasan (2001). "Kontrast Duyarlık ve Renk Görme", Türk Oftalmoloji Dergisi, 31:725-737.

http://www.oftalmoloji.org/sayilar/90/ buyuk/2001-6-725-737.pdf (15.11.2013)

Kandinsky, Wassily (2013). Sanatta Ruhsallık Üzerine, Çev. Gülin Ekinci, İstanbul: Altıkırkbeş Yayın.

Kaufmann, Lioyd (1974). Sight and Mind: An Introduction To Visual Perception, NewYork, Londra, Toronto: Oxford Üniversitesi Yayınları.

Klee, Paul (1987). Çağdaş Sanat Kuramı, Çev. Mehmet Dündar, Ankara: Dost Kitabevi Yayınları
Moszynska, Anna (1993). Abstract Art, Londra: Thames And Hudson Yayınları.

Sérullaz, Maurice (1983). Empresyonizm Sanat Ansiklopedisi, Çev. Devrim Erbil, 1. Baskı, İstanbul: Remzi Kitabevi.

Temizsoylu, Nuri (1987). Renk ve Resimde Kullanımı, İstanbul: Mimar Sinan Üniversitesi Yayınları.

Tuğal, Sibel Avcı (2012). Oluşum Süreci içinde Op Art, İstanbul: Hayalperest Yayınevi.

Tunalı, İsmail (1983). Felsefenin Işığında Modern Resim, İstanbul: Remzi Kitabevi Yayınları.

Warner, Deborah Jean, (2005).“The Claude Glass: Use and Meaning of the Black Mirror in Western Art", Technology and Culture, 4 (46): 865-866.

Yazıcıoğlu, İclal (1990). "Renk Teorileriyle illgili Tarihsel Bir İnceleme”, Yayınlanmamış Yüksek Lisans Tezi, İzmir: Dokuz Eylül Üniversitesi Sosyal Bilimler Enstitüsü

\section{Görsel Kaynaklar}

Resim 1. Sir Joshua Reynolds, 'Laydi Elizabeth Delmé ve Çocukları' http://commons.wikimedia.org/wiki/File:Sir_Joshua_ Reynolds_Lady_Elizabeth_Delm\%C3\%A9_and_Her_ Children_-_Google_Art_Project.jpg (20.11.2013)

Resim 2. Thomas Gainsborough. 'Köprülü Peyzaj' https://images.nga.gov/en/search/do_quick_search. html?q=\%221937.1.107\%22\&page=1 (20.11.2013)

Resim 3. John Constable, 'Saman Arabası' http://en.wikipedia.org/wiki/File:John_Constable_The_Hay_ Wain.jpg (17. 11.2013)

Resim 4. J.M.W. Turner, 'Yağmur, Buhar ve Hız' M.Harden,http://www.ibiblio.org/wm/paint/auth/turner/i/ rain-steam-speed.jpg (01.12.2013)

Resim 5. Wassily Kandinsky, 'Kompozisyon 7' http://www.ibiblio.org/wm/paint/auth/kandinsky/ kandinsky.comp-7.jpg (01.12.2013)

Resim 6. Claude Monet, 'ilkbaharda Tarlalar' http://www.monetpainting.net/paintings/underpoplars. php?search_by=popular\% 20 (02.12.2013)

Resim 7. Paul Cézanne, 'Zencefil Kavanozlu ve Patlıcanlı Natürmort' http://www.metmuseum.org Collectionssearch-thecollectio ns/435881(08.12.2013) 
Resim 8. Georges. Seurat, ‘Grande Jatte Adası́nda Bir Pazar Öğleden Sonrasi'

http://tr.wikipedia.org/wiki/Dosya:Georges_Seurat_031.jpg (15.11.2013)

Resim 9. Frantisek Kupka, 'Newton Diski'

http://www.wikipaintings.org/en/frantisek-kupka/disks-ofnewton-study-for-fugue-in-two-colors (08.12.2013)

Resim10. Robert Delanuay, 'Güneş ve Ay' http://www.flickr.com/photos/infoaesthete/8745463464/ sizes/o/in/photostream/(01.12.2013)

Resim 11. Morgan Russel, 'Koyu Mavi Menekşede Birlik' http://uploads5.wikipaintings.org/images/morgan-russell/ synchromy-in-blue-violet-1912.jpg (01.12.2013)

Resim 12. Macdonald Wright Stanton,'Sinkroni Kavrami' http://prints.encore-editions.com/0/500/stantonmacdonald-wright-conception-synchromy.jpg (09.12.2013)

Resim 13. Gino Severini,'Dansçi' http://c300221.r21.cf1.rackcdn.com/seadancer-gino-severini1883-1966-1334948276_b.jpg (09.12.2013)

Resim 14. Victor Vasarely, 'Mor İçinde Çok katlı Izgara' http://www.rogallery.com/Vasarely_Victor/w-1088/ vasarely-printpurple.html (01.12.2013) 